\title{
Non-pharmacological approach to pain in endometriosis*
}

\author{
Abordagem não farmacológica da dor em endometriose
}

\author{
Alessandra Bernadete Trovó de Marqui ${ }^{1}$ \\ ${ }^{*}$ Received from Federal University of Triângulo Mineiro, Uberaba, MG, Brazil.
}

DOI 10.5935/1806-0013.20140065

\section{ABSTRACT}

BACKGROUND AND OBJECTIVES: Endometriosis is a gynecological condition primarily characterized by chronic pain and infertility. To treat endometriosis-induced pain, the focus is still based on conventional approaches. However, non-pharmacological therapies are new options, but there is still no consensus about the use of such therapies as effective resource for pain control. In light of the above, this study aimed at contributing to the knowledge in this area and at analyzing the literature about the application of such techniques to treat endometriosis pain.

CONTENTS: Pubmed database was queried, without period restriction, using the word endometriosis crossed with acupuncture, massage, Pilates and cognitive behavioral therapy. Electronic query has identified 61 scientific studies and, according to preestablished inclusion and exclusion criteria, seven were selected for reading. Three of them have used acupuncture, two have used massage and two cognitive behavioral therapy to relieve endometriosis pain. Pilates method was not applied to control endometriosis pain. All studies have shown effectiveness of the techniques used to improve endometriosis chronic pain.

CONCLUSION: It was clear that knowledge about this subject is scarce, suggesting the need for additional studies. Also, such options should be incorporated to traditional approaches offered to patients with endometriosis for having low cost, few adverse effects and for presenting satisfactory results for pain relief.

Keywords: Chronic pain, Endometriosis, Non-pharmacological approach, Psychology, Therapy.

\section{Federal University of Triângulo Mineiro, Uberaba, MG, Brazil.}

Submitted in June 13, 2014.

Accepted for publication in October 27, 2014

Conflict of interests: none. Sponsoring sources: none.

Correspondence to:

Alessandra Bernadete Trovó de Marqui

UFTM, Instituto de Ciências Biológicas e Naturais/ICBN, Dept ${ }^{\circ}$ de Patologia, Gené-

tica e Evoluçăo, Disciplina de Genética, Campus I

Praça Manoel Terra, 330

38015-050 Uberaba, MG, Brasil.

E-mail: alessandratrovo@hotmail.com

(C) Sociedade Brasileira para o Estudo da Dor

\section{RESUMO}

JUSTIFICATIVA E OBJETIVOS: A endometriose é uma condição ginecológica caracterizada principalmente por dor crônica e infertilidade. Para tratamento da dor associada à endometriose, o foco ainda é baseado no tratamento convencional. No entanto, as terapias com abordagem não farmacológica constituem novas opçóes, mas ainda não há consenso sobre a utilização dessas terapias como recurso efetivo no controle da dor. Diante do exposto, este estudo teve como objetivo contribuir com os conhecimentos nesta área e analisar a produção bibliográfica a respeito da aplicação dessas técnicas no tratamento da dor em endometriose.

CONTEÚDO: Foi realizada uma pesquisa bibliográfica, no Pubmed, sem restriçáo de período, utilizando o termo endometriosis cruzado com acupuncture, massage, Pilates e cognitive behavioral therapy. Foram identificados na busca eletrônica 61 artigos científicos e, de acordo com os critérios de inclusão e exclusão pré-estabelecidos, sete foram selecionados para leitura. Três deles empregaram acupuntura, dois massagem e dois terapia cognitiva comportamental para alívio da dor em endometriose. $\mathrm{O}$ método Pilates não foi aplicado para controle da dor em endometriose. Todos os estudos mostraram eficácia das técnicas empregadas na redução da dor crônica nessa doença.

CONCLUSÃO: Ficou evidente que a produção de conhecimento sobre a temática é escassa, o que sugere a necessidade de estudos adicionais. Ainda, tais opçóes deveriam ser incorporadas ao tratamento convencional oferecido a pacientes com endometriose por serem de baixo custo, exibirem poucos efeitos adversos e apresentarem resultados satisfatórios para o alívio da dor.

Descritores: Dor crônica, Endometriose, Psicologia, Terapêutica, Tratamento não farmacológico.

\section{INTRODUCTION}

Endometriosis is a chronic gynecological condition primarily characterized by chronic pain and infertility, which affects approximately $10 \%$ of females in reproductive age. It is defined by the presence of endometrial tissue outside the uterine cavity. Symptoms include dysmenorrhea, dyspareunia, chronic pelvic pain (CPP), dysuria, dyschezia and infertility.

Dysmenorrhea, also known as menstrual cramps, is pelvic pain before or during the menstrual period. Dyspareunia is pain at sexual intercourse, and dysuria and dyschesia are defined as pain at micturition and defecation, respectively ${ }^{1}$. Two independent studies have shown dysmenorrhea prevalence of $94.4^{2}$ and $57^{3}$; 
$74.3^{2}$ and $60 \%{ }^{3}$ of females reporting chronic pain, and dyspareunia was present in $70.1^{2}$ and $47 \%{ }^{3}$ of investigated patients.

From patients with dyspareunia, $80 \%$ have changed their sexual behavior by interrupting or avoiding sexual intercourse due to pain $^{3}$. Among most common pain-related coexisting symptoms there are back and leg pain in $75.7 \%$ and dizziness / headaches in $60.7 \%{ }^{2}$. Due to symptoms, patients have decreased productivity at work and high absenteeism rates ${ }^{2-4}$.

Constant pain reported by endometriosis patients has negative direct and indirect impact on their lives. So, to control this pain, hormone-based conventional approaches and/or surgery are used. Pharmacological approaches trigger several adverse effects (hot flushes, emotional changes, decreased bone mass, vaginal dryness, weight gain, acne, decreased libido and hirsutism, among others) and surgery is associated to risk of recurrence or complications ${ }^{5}$. A recent study has shown that expenditures with endometriosis surgeries corresponded to $29 \%$ and drugs were responsible for $10 \%$ of health care costs ${ }^{6}$.

Endometriosis-related pain is still managed by conventional methods. However, physiotherapeutic therapies (Pilates and massage), acupuncture and psychology (cognitive behavioral therapy (CBT)) are new options; however, there is no consensus about the use of such therapies as effective resource to control pain.

In light of the above, this study aimed at contributing to the knowledge in this area and at analyzing the literature about the application of such techniques to handle endometriosis pain.

\section{CONTENTS}

This is a literature research carried out in Pubmed, without period restriction, using the term endometriosis crossed with acupuncture, massage, Pilates and cognitive behavioral therapy. Inclusion criteria were: 1) being closely related to the objective of the study, being selection carried out by analyzing the title and/or the abstract; 2) being published in English or Portu- guese; 3) with free availability of the whole text; 4) with application of $\operatorname{method}(s)$ in humans; 5) being original/research articles. Review and update articles, letters to the editor, case reports and experience reports were excluded.

Electronic query has identified 61 scientific articles and seven have met established criteria and were included in the study.

Results of this query are summarized in table 1.

Three studies have evaluated acupuncture to control endometriosis pain $^{7-9}$. In the 2002 study, 67 patients with endometriosis and dysmenorrhea were divided in two groups being 37 submitted to ear acupuncture (EAT) and 30 treated with Chinese drugs (CD). Pre and post treatment scores for the EAT group were $12.19 \pm 2.42$ and $5.53 \pm 2.17$, respectively, as compared to $11.22 \pm 3.11$ (pre) and $10.34 \pm 3.51$ (post treatment) for the CD group. When comparing therapeutic effects of both treatments, total effective rate was $91.9 \%$ for EAT and $60 \%$ for CD.

Both results have highlighted the superiority of acupuncture to decrease endometriosis pain ${ }^{7}$. A Japanese acupuncture style was applied to 14 young females (mean age of 17 years) with diagnosis of endometriosis and $\mathrm{CPP}^{8}$. Nine patients were submitted to active acupuncture and five to sham acupuncture in a total of 16 sessions, twice a week for eight consecutive weeks. Mean (standard deviation) pain levels before treatment were 7.7 (2.3) and 7.6 (0.9) for active and sham acupuncture, respectively. Four weeks later, improvement was significantly higher for the active acupuncture group as compared to control, that is, $-4.8(2.4)$ versus $-1.4(2.1)$, respectively. Eight weeks and 6 months later, pain decrease in the active group remained slightly better, but the difference between groups was not statistically significant [active versus sham 8 weeks later: -4.3 (3.6) versus -3.8 (1.7); active versus sham 6 months later: -3.6 (3.0) versus $-2.8(3.8)]^{8}$. In a study by Rubi-Klein et al. ${ }^{9}, 83$ patients were divided in two groups and each has received two units of 10 acupuncture sessions, twice a week, for five weeks.

Group 1 was made up of 42 patients with endometriosis and group 2 was made up of 41 . In unit 1 , group 1 has received acu-

Table 1. Results of Pubmed electronic query

\begin{tabular}{|c|c|c|c|c|}
\hline Authors & Keywords & $\begin{array}{l}\text { \# of identified } \\
\text { articles }\end{array}$ & \# of excluded articles/Reason & $\begin{array}{l}\text { \# of selected articles } \\
\text { for reading }\end{array}$ \\
\hline $\begin{array}{l}\text { Xiang et al. }{ }^{7} \\
\text { Wayne et al. }^{8} \\
\text { Rubi-Klein et al. }{ }^{9}\end{array}$ & $\begin{array}{l}\text { Endometriosis and } \\
\text { acupuncture }\end{array}$ & 35 & $\begin{array}{c}32 \text { excluded } \\
12 \text { review articles } \\
8 \text { studies in different languages ( } 7 \text { in Chinese) } \\
1 \text { letter to the editor } \\
7 \text { unrelated to the subject } \\
3 \text { review articles published in different language } \\
1 \text { case report }\end{array}$ & 3 \\
\hline $\begin{array}{l}\text { Valiani et al. }{ }^{10} \\
\text { Missmer \& Bove }{ }^{11}\end{array}$ & $\begin{array}{c}\text { Endometriosis and } \\
\text { massage }\end{array}$ & 5 & $\begin{array}{l}3 \text { excluded } \\
2 \text { case reports } \\
1 \text { unrelated to the subject }\end{array}$ & 2 \\
\hline- & $\begin{array}{c}\text { Endometriosis and } \\
\text { Pilates }\end{array}$ & 8 & $\begin{array}{l}8 \text { excluded } \\
\text { No article has mentioned Pilates method for endo- } \\
\text { metriosis in the title and/or abstract }\end{array}$ & - \\
\hline $\begin{array}{l}\text { Lorençatto et al. }{ }^{12} \\
\text { Mendes \& Figueiredo }{ }^{13}\end{array}$ & $\begin{array}{l}\text { Endometriosis and } \\
\text { cognitive behavio- } \\
\text { ral therapy }\end{array}$ & 13 & $\begin{array}{c}11 \text { excluded } \\
3 \text { review articles } \\
8 \text { unrelated to the subject }\end{array}$ & 2 \\
\hline Total & & 61 & 54 & 7 \\
\hline
\end{tabular}


puncture and group 2 has not, and in unit 2 the opposite was true, according to crossover design. Group 1 had significant pain intensity decrease after the first 10 sessions and group 2 had pain relief after crossover.

Only two studies have used massage to control endometriosis pain ${ }^{10,11}$. In one of them, massage was applied to 23 patients with endometriosis and dysmenorrhea, and visual analog scale (VAS) scores were measured in three different periods, as shown in table 2 . Before intervention, approximately $52 \%$ of patients referred severe pain and six weeks after intervention $65 \%$ of them reported lack of menstrual pain ${ }^{10}$.

The other study has used massage and acupuncture for leg pain relief $^{11}$. From 94 patients with endometriosis, 48 (51\%) have reported this symptom. Leg pain was bilateral, left unilateral and right unilateral in 59, 24 and $17 \%$ of patients, respectively, with median VAS score of 5 . In $46 \%$ of cases, the clinician has not suggested any treatment option for this symptom. However, most females have undergone several types of treatments and $2 / 3$ of them have reported benefits. Massage and acupuncture were applied to 61 (25) and 31\% (12), respectively, with pain improvement reported by 79 (19) and 67\% (8) of cases ${ }^{11}$. Pilates method was not applied to endometriosis patients to control pain.

Two studies have evaluated CBT to control endometriosis pain ${ }^{12,13}$. The second study proposed the use of CBT in Portuguese females with endometriosis, aiming at better knowing the disease in a psychological perspective, in its qualitative and quantitative dimension. CBT design was based on psychological and physical symptoms (anxiety, stress, depression, pain, fatigue), relationships (partner/sexuality, family and social) and work ${ }^{13}$.

The first study has evaluated 128 Brazilian females with endometriosis, equally divided in two groups, receiving or not intervention of the Group of Psychological and Physiotherapeutic Support to Females with Endometriosis (GAPFAME) ${ }^{12}$. GAPFAME was offered to all females of the Endometriosis Outpatient Setting, CAISM/UNICAMP, as additional treatment to other usual procedures (clinical and surgical).

It was defined and structured based on CBT principles and also on reported experiences of other chronic pain multidisciplinary interventions, having as primary objective to convey information about endometriosis and to promote physical, emotional and social well being rehabilitation of females with the disease. It was structured in 10 weekly meetings lasting 2:30 hours, being the first hour dedicated to physiotherapy and the re- maining time to psychological intervention. Pain intensity was measured with VAS in the support and without intervention groups and values obtained were $4.2 \pm 3.3$ and $6.6 \pm 2.4$, respectively, expressed as mean \pm standard deviation.

In the support group, pain levels were weekly evaluated and there has been significant decrease along time (from first to ninth week, $\mathrm{p}<0.0001$ ), reaching 2.6 2.6 in the last week. Mean pain found in the group without intervention was higher than that reported by females in the beginning of the support group. However, there have been no specific selection criteria that would justify VAS differences. At the end of groups, reports on improvements with regard to physical and emotional aspects associated to pain decrease were frequent. In this sense, the intervention proposed to the support group has fully met its objectives, because it has promoted pain and depression scores decrease, thus contributing to improve quality of life of such patients ${ }^{12}$.

\section{DISCUSSION}

Chronic pain is the symptom afflicting the most endometriosis patients, because it has negative impact on quality of life, affecting relationships, working capacity and functionality, among other daily life aspects.

Results of presented studies have shown that acupuncture was effective to treat endometriosis pain, but two of them have reinforced the need for additional research ${ }^{8,9}$. One of them has concluded that the small sample size used in this pilot study had limited the reaching of final conclusions, but has emphasized the receptivity of young endometriosis patients to the treatment ${ }^{8}$. One literature review published in $2011^{14}$ has identified 14 studies using acupuncture to control endometriosis pain.

However, only one has met inclusion criteria and was considered in this review. Authors have concluded that scientific evidence supporting the efficacy of acupuncture to treat endometriosis pain is limited, based on results of a single study ${ }^{14}$. Acupuncture has been successfully used to treat pelvic pain, infertility and dysmenorrhea, all frequent endometriosis symptoms ${ }^{15}$. It has also been used as satisfactory complementary therapy to treat pain in dentistry ${ }^{16}$. An interesting finding was that seven articles published in Chinese have used acupuncture to treat endometriosis pain. This was because acupuncture is one of the oldest and most respected sciences, especially by Eastern people, primarily in China, where this ancient technique started to be spread as family secret ${ }^{16}$.

Table 2. Menstrual pain scores according to visual analog scale in three different periods

\begin{tabular}{lccc}
\hline Menstrual pain intensity & $\begin{array}{c}\text { Before intervention } \\
(\mathrm{n} \& \%)\end{array}$ & $\begin{array}{c}\text { Immediately after intervention } \\
(\mathrm{n} \& \%)\end{array}$ & $\begin{array}{c}\text { Six weeks after intervention } \\
\text { (n \& \%) }\end{array}$ \\
\hline 0 (no pain) & $0(0)$ & $8(34.8)$ & $15(65.2)$ \\
$1-3$ (mild) & $1(4.3)$ & $6(26)$ & $7(30.5)$ \\
$4-6$ (moderate) & $10(43.4)$ & $5(21.7)$ & $1(4.3)$ \\
$7-10$ (severe) & $12(52.3)$ & $4(17.3)$ & $0(0)$ \\
Total & $23(100)$ & $23(100)$ & $23(100)$ \\
\hline
\end{tabular}


Massage was also effective to handle endometriosis pain, minimizing menstrual and leg pain symptoms, being them considered related to and coexisting with endometriosis, respectively $y^{10,11}$.

Although there are no articles published about Pilates for endometriosis, two studies have highlighted the efficacy of such method to decrease chronic spinal pain ${ }^{17}$ and primary dysmenorrhea $^{18}$. The first study has identified significant $66 \%$ pain decrease in the experimental group (20 college students aged between 18 and 25 years with diagnosis of non-structural scoliosis $\mathrm{p}=0002)^{17}$.

The 2012 research has submitted dysmenorrhea patients to a protocol of 16 ground and ball exercises for the pelvic region based on the Pilates method. Mean pain score, according to VAS before treatment was $7.89 \pm 1.96$ and after treatment it was $2.56 \pm 0.56(\mathrm{p}<0.001)^{18}$. Both results have shown that Pilates has provided pain relief with excellent results ${ }^{17,18}$. In this sense, and considering the lack of scientific articles applying this technique to control endometriosis pain, the use of this method as nonpharmacological resource to treat endometriosis pain is suggested.

With regard to CBT, another study has confirmed the success of this strategy to handle pain ${ }^{19}$. In this study, 79 patients (72 females) with chronic pain of different etiologies have participated in a Chronic Pain Control Program with psycho-educative approach and cognitive-behavioral focus, leaded by a nurse and carried out by a multidisciplinary team (physiotherapist, nurse, psychologist, occupational therapist and nutritionist). At the end of the program (duration: eight weeks), there has been significant improvement in pain intensity, incapacity and depressive symptoms ${ }^{19}$.

This study results have shown the benefits of this type of chronic pain manaagement and have confirmed those previously published by Lorençatto et at. ${ }^{12}$. Authors of the 2012 study suggest that such intervention should be used by specialized pain management centers, rehabilitation centers or preventive medicine centers ${ }^{19}$. Lorençatto et al. ${ }^{12}$, in turn, recommend the incorporation of this approach to traditional approaches offered to endometriosis patients. However, this would require the participation of a multi-professional team for its application and effectiveness.

It is also worth considering that the economic impact of such techniques and the cost of the sessions are not significant and burdensome for patients. Alternative treatment is safe, has no contraindications and adverse effects are virtually inexistent, provided patients are assisted by a qualified professional and that technique principles are strictly followed, considering systemic conditions of each individual.

Data have shown that non-pharmacological/surgical endometriosis pain treatment is still hardly explored and used in the health area. In this direction, further studies should be carried out to understand the real contribution of such therapies to relieve pain. However, the few published studies have shown promising results of such techniques to treat endometriosis pain.

\section{CONCLUSION}

The few investigation presented in this study have shown that acupuncture, massage and CBT have provided pain scores decrease in endometriosis patients. However, further studies on this subject should be carried out, with larger samples and other conditions characterized by chronic pain, to prove the results of studies presented herein. Such options should be incorporated to conventional approaches offered to endometriosis patients for having low cost, few side-effects and satisfactory results for pain relief. Still, it was clear the importance of including a multiprofessional team to treat endometriosis, due to the complexity of this gynecological condition.

\section{REFERENCES}

1. Bulun SE. Endometriosis. N Engl J Med. 2009;360(3):268-79.

2. Fourquet J, Gao X, Zavala D, Orengo JC, Abac S, Ruiz A, et al. Patients' report on how endometriosis affects health, work, and daily life. Fertil Steril. 2010;93(7):2424-8.

3. De Graaff AA, D'Hooghe TM, Dunselman GA, Dirksen CD, Hummelshoj L; WERF EndoCost Consortium, et al. The significant effect of endometriosis on physical, mental and social wellbeing: results from an international cross-sectional survey. Hum Reprod. 2013;28(10):2677-85.

4. Fourquet J, Báez L, Figueroa M, Iriarte RI, Flores I. Quantification of the impact of endometriosis symptoms on health-related quality of life and work productivity. Fertil Steril. 2011;96(1):107-12.

5. Vercellini P, Viganò P, Somigliana E, Fedele L. Endometriosis: pathogenesis and treatment. Nat Rev Endocrinol. 2014;10(5):261-75.

6. Simoens S, Dunselman G, Dirksen C, Hummelshoj L, Bokor A, Brandes I, et al. The burden of endometriosis: costs and quality of life of women with endometriosis and treated in referral centers. Hum Reprod. 2012;27(5):1292-9.

7. Xiang D, Situ Y, Liang X, Cheng L, Zhang G. Ear acupuncture therapy for 37 cases of dysmenorrhea due to endometriosis. J Tradit Chin Med. 2002;22(4):282-5.

8. Wayne PM, Kerr CE, Schnyer RN, Legedza AT, Savetsky-German J, Shields MH, et al. Japanese-style acupuncture for endometriosis-related pelvic pain in adolescents and young women: results of a randomized sham-controlled trial. J Pediatr Adolesc Gynecol. 2008;21(5):247-57.

9. Rubi-Klein K, Kucera-Sliutz E, Nissel H, Bijak M, Stockenhuber D, Fink M, et al. Is acupuncture in addition to conventional medicine effective as pain treatment for endometriosis? A randomised controlled cross-over trial. Eur J Obstet Gynecol Reprod Biol. 2010;153(1):90-3.

10. Valiani M, Ghasemi N, Bahadoran P, Heshmat R. The effects of massage therapy on dysmenorrhea caused by endometriosis. Iran J Nurs Midwifery Res. 2010;15(4):167-71.

11. Missmer SA, Bove GM. A pilot study of the prevalence of leg pain among women with endometriosis. J Bodyw Mov Ther. 2011;15(3):304-8.

12. Lorençatto C, Vieira MJ, Marques A, Benetti-Pinto CL, Petta CA. [Evaluation of pain and depression in women with endometriosis after a multi- professional group intervention]. Rev Assoc Med Bras. 2007;53(5):433-8. Portuguese.

13. Mendes N, Figueiredo B. Psychological approach to endometriosis: women's pain experience and quality of life improvement. Psic Saúde \& Doenças, 2012;13(1):36-48.

14. Zhu X, Hamilton KD, McNicol ED. Acupuncture for pain in endometriosis. Cochrane Database Syst Rev. 2011;(9):CD007864.

15. Rocha AL, Reis FM, Petraglia F. New trends for the medical treatment of endometriosis. Expert Opin Investig Drugs. 2012;21(7):905-19.

16. Boleta-Ceranto DC, Alves T, Alende FL. O efeito da acupuntura no controle da dor na odontologia. Arq Ciênc Saúde Unipar, Umuarama. 2008;12(2):143-8.

17. Araújo ME, Silva EB, Vieira PC, Cader SA, Mello DB, Dantas EH. Redução da dor crônica associada à escoliose não estrutural, em universitárias submetidas ao método Pilates. Motriz, Rio Claro. 2010;16(4):958-66.

18. Araújo LM, Silva JM, Bastos WT, Ventura PL. Diminuição da dor em mulheres com dismenorreia primária, tratadas pelo método Pilates. Rev Dor. São Paulo, 2012;13(2):119-23.

19. Salvetti MG, Cobelo A, Vernalha PM, Vianna CI, Canarezi LC, Calegare RG. Efeitos de um programa psicoeducativo no controle da dor crônica. Rev Latino-Am Enfermagem. 2012, 20(5):1-7. 